iv vein that ho introdnoed the adherive pinations $\mathrm{He}_{0}$ in vined that the obutacle to be orencome in permanently aing and core consisted in a disordered state of the brofintice and that the general preseure on the limb y u d beneficinlly on the ulcer, by assisting their function. and in another part of his work he states that the principal Air coencioned by deficiency of power in the absorbent ressels.

Dr. Underwood and Mr. Whateley have not once alluded to the existence of varicose reins in the leg as being a cuve of ulcers, although they are both rery able and strenuous advocates of pressure. The first of these writers has not even mentioned this condition of the reins in any part of his treatise; and the latter has only once incidentally adverted to it as being a state benefited by the use of the bandage, in common with some other adrantages attending its employment. He attributes all the blame to nature for making our legs where they are. Both these writers systematically resorted to compression as the agent calculated to do the greatest good, though with no very precise idea as to the exact character of the evil with which they had to contend.

Sir Everard Home has recognised the varicose state in connexion with ulcers of the leg more than any other person who has treated of this subject. But then he speaks of this division of ulcers as being merely " attended" with vericose veins; and adds that "they have their origin from some accidental cause." Nor does Sir E. Home allude to that unhealthiness of the outer structure of the limb, which is mainly produced by the prior condition of the venous channels.

More recently, the pathological dependence of ulcers of the legs upon varicose veins has been clearly laid down by Mr. Critchett. He alludes to five different ways in which varix may terminate, each of which may be a forerunner of the succeeding stage, until the condition of ulceration is actually reached.* To Mr. Chapman, also, we are in-

* Lancet, October 7 th, 1848 . debted for a concies expocition of correet riows upon thin oubject. And in all the great syotomatic works on surgery published in late jears, wo find that the pathologs of this question is based upon sound and definite principles.

[To be continued.]

\section{MEDICAL STATISTICS OF THE ARMY OF THE CRIMEA.}

By an Eye WrTwess.

THE following may perhaps be interesting, showing, as it does, the present healthy condition of our splendid army in the Crimea, in comparison with a sketch I give of the glorious army when landing in that country.

The subjoined tabular statements show pretty clearly the amount of disease among our forces in the Crimea. This is the return of one division of the army only, containing an arerage number of 6,000 ; and this division may be considered an average of all others. Some are more, of course, and others are less; yet it may be roughly taken as an average. It shows that one man in six died either by wounds or disease in the first six months in the Crimea (in the regimental hospitals only), leaving out of the question those who died after removal to other hospitals, or invalided. Of course, it does not include those killed, as they never entered hospital. The deaths in the last three months in 1855, shew 81-100th per cent: those of the month of January 1856, shew a mortality of 2-10ths.

It must be very gratifying to the country at large to know the army is so healthy, and still more pleasant to the army medical officers, who have now time to rest on their oars, and review the past, and also to make a few suggestions and preparations for the comforts of our men in the future, should we have another campaign.

*T $\triangle B L E$ I.-Sherving the number of Officers and Men of all Arms belonging to a Division of the Army 6,000 strong, who were Admitted, Died, ard were Discharged, during the first Six Months after landing in the Crimea, from Wounds and Disease.

\begin{tabular}{|c|c|c|c|c|c|c|}
\hline & Admitted. & Died. & Discharged to duty. & Dis. to Gen. IIosp. & Dis. to England. & Remaining \\
\hline $\begin{array}{l}\text { Officers } . . . \ldots \ldots \\
\text { Men } . . . . \ldots \ldots\end{array}$ & $\begin{array}{rrrr}\text { s. } & & \text { ॠ. } \\
188 & \ldots & \text { s9 } \\
5201 & \ldots & 1074\end{array}$ & $\begin{array}{rll}7 & \ldots & \\
862 & \ldots . & 71\end{array}$ & $\begin{array}{rrrr}\text { s. } & & \text { w. } \\
131 & \ldots & 7 \\
2387 & \ldots & 152\end{array}$ & $\begin{array}{rlr}8 . & & { }_{i j} \\
1507 & \ldots \ldots & 745\end{array}$ & $\begin{array}{llll}\text { is. } & & \text { w. } \\
33 & \ldots & \text { jo } \\
33 & \ldots & 101\end{array}$ & $\begin{aligned}{ }_{6}^{8} & \\
502 & \ldots \ldots\end{aligned}$ \\
\hline
\end{tabular}

REXark-I cannot, of course, say how many of those have since died who were invalided either to General Hospital, England, or of those remaining.

+TaBLE II.-Shewing the Admissions, Deaths, and Discharges, during the last Three Months of the last year, 1855. (Sick and wounded together.)

Previously in Hospital .................. 467

Admitted........................... 2018

Died............................ $\frac{2485}{49}$

Discbarged .......................... 2035

Romaining 31st December .............. 401

\begin{tabular}{|c|c|c|c|}
\hline Diseases. & Admitted. & | Discharged. & Fatal. \\
\hline \multirow[t]{2}{*}{ 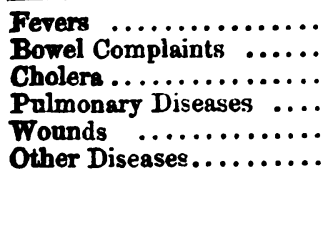 } & $\begin{array}{r}218 \\
497 \\
20 \\
350 \\
68 \\
865\end{array}$ & $\begin{array}{r}240 \\
595 \\
11 \\
274 \\
120 \\
795\end{array}$ & $\begin{array}{r}14 \\
10 \\
11 \\
4 \\
4 \\
6\end{array}$ \\
\hline & 2018 & 2035 & 40 \\
\hline
\end{tabular}

†TABLE III.-Sheroing the Admissions, Discharges, and Deaths, for the month of January 1856.

Remaining 31st December .............. $\$ 01$

Admitted.......................... 459

$\overline{\mathbf{8 6 0}}$

Died .......................... 12

Discharged $. . \ldots \ldots \ldots \ldots \ldots \ldots \ldots \ldots \ldots \ldots, 611$

Remaining 31st January .............. 237

\begin{tabular}{|c|c|c|c|}
\hline Diserses. & Admitted. & Discharged. & Fatal. \\
\hline \multirow[t]{2}{*}{ 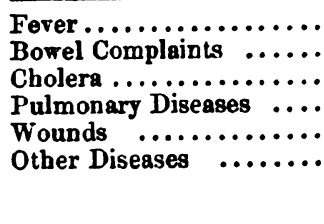 } & \begin{tabular}{r|}
48 \\
53 \\
0 \\
114 \\
16 \\
228
\end{tabular} & $\begin{array}{r}51 \\
90 \\
0 \\
158 \\
38 \\
271\end{array}$ & $\begin{array}{l}1 \\
1 \\
0 \\
6 \\
1 \\
3\end{array}$ \\
\hline & 458 & 011 & 12 \\
\hline
\end{tabular}


TAs: IV. - Shewing the percentage of Admiesions and Doaths to Strength for the different periods, as above.

\begin{tabular}{|c|c|c|}
\hline & $\begin{array}{l}\text { Admissions to } \\
\text { Strength. }\end{array}$ & $\begin{array}{l}\text { Deaths to } \\
\text { Strength. }\end{array}$ \\
\hline $\begin{array}{l}\text {-For Six Months after Land. } \\
\text { ing, } 1854 \ldots \ldots \ldots \ldots \ldots \\
\text { +For Isast Quarter of } 1855 \ldots \\
\text { fFor January } 1856 \ldots \ldots \ldots \text {. }\end{array}$ & $\begin{array}{r}100 \cdot 86 \\
33 \cdot 6.3 \\
7.65\end{array}$ & $\begin{array}{c}15.87 \\
0 \cdot 81 \\
0.2\end{array}$ \\
\hline
\end{tabular}

Rxunkx.-The difference of period should be borne in mind.

\section{CASES IN MIDWIFERY.}

By Thoxas Raprond, M.D., F.R.C.P.Edin., etc., Consulting Physician to St. Mary's Hospital, Manchester.

\section{[Continued from page 105.]}

Case xv. March 11th, 1824. Early in the morning, Mr. Dadley desired me to visit a hospital patient living in Miller's Lane, to whom he had been called by Mrs. Frost. She was in labour of her seventh child. Mr. Dadley found her very much reduced from hæmorrhage, which had continued for some time previously to his being sent for, and which now recurred with greater violence during the pains, which were frequent and short. The os uteri was low down in the pelvis, soft, and dilated to about the size of a half-crown. He discovered a portion of the placenta with the membranes, and higher up, the head of the child. At this time a messenger was dispatched for me; but before I arrived, she was dead. Mr. Dadley stated the symptoms of exhaustion became so urgent, that he felt he should not be justified in waiting for me, and therefore he determined on immediate delivery. He passed his hand by the side of the placenta, and then ruptured the membranes: the patient immediately fainted and died.

Permission was obtained for a post mortem examination. The aspect of the body was white and exsanguined. The abdominal viscera were pale. The uterus was flaccid and large in size; on cutting through its parietes, they were found thinner than usual. The placenta was also thin, and extensively connected to the right side of the cervix and body of the womb. The os uteri was nearly fully opened, and within it there was a narrow loosened portion of placenta.

Rexarks. Although I did not see the patient during her life, there can be no doubt the vital powers were very greatly exhausted from the hæmorrhage, which had been incessant for a very considerable length of time.

The case is an example of an opposite character to some of those which are already cited. The atonic state of the uterus, evinced by the very feeble pains, and further proved by the post mortem examination, no doubt mainly contributed to the fatal issue. If the fundus and body had acted energetically at an early period of the labour, the os uteri being so soft and unresistant, it is most probable the woman would have been saved under judicious obstetric management.

CABE xvI. April 25th, 1825. Through the kindness of my colleague Mr. Fawdington, I was present at the post mortem examination of a hospital patient. I was told she had lost a very large quantity of blood, which did not escape by large impetuous gushes, which sometimes immediately destroy a woman, but by an incessant dribbling discharge. $\Delta s$ her dissolution seemed impending, it was deemed right to deliver her, although the os uteri was high, felt rigid, and was very little dilated. Mr. Fawdington stated that he performed the operation very slowly and carefully, but with great difficulty. The child was stillborn. She died on the second day after her delivery.

On inspecting the body, it was white and exsanguine. There was a little watery fluid in the peritoneal carity. The uterus was soft and larger than usual. The os was ragged, there being several lacerations through its tissue, which appeared as if it was gangrenous.

CASE XVIr. March 11th, 1830. Farly in the morning, Mrs. - midwife, sent for me to see a patient, whom the messenger stated to be in labour, and in great danger. She was in the eighth month of her sixth pregnanc. She had flooded, more or less constantly, for a fortnight. Her labour began the evening before, and she had strong pains during the whole of the night, which were accompanied by an increased discharge of blood. She was very much exhausted. Her countenance was extremely pale. The surface of the body felt very cold. Her pulse was scarcely perceptible. There was great restlessness, and she gasped for breath. The os uteri was soft, and dilated to about the size of a dollar. A portion of the placenta protruded through it into the vagina. As her death was inevitable, I deemed it right only to tighten the bandage, which was already about her, and to pass a piece of sponge per vaginam, more for the sake of satisfaction to her friends than to serve any other purpose. Brandy and water, etc., were ordered, but she bad difficulty in swallowing. She died in about an hour.

Consent was obtained to examine the body the day following. It was white, as if altogether drained of blood. There was extreme paleness observable in the abdominal viscera. On cutting into the uterus, and opening the membranes, some liquor amnii escaped. The child lay in a natural position, and its body was very white, as if it had also lost its blood. The placenta was remarkably thin, and extensively connected; it covered the os, the cervix, and the body of the womb; it was more like a placental bag than like (as it is usually called) "a cake". That portion of this organ into which the funis was inserted was placed nearly over the centre of the os uteri. This opening was soft and considerably dilated, and was filled with the placenta, which was lacerated, and its tissue loaded with coagulated blood.

REMARRs. The midwife was most unpardonable in allowing this poor creature to bleed to death without earlier sending for further assistance. What individual efforts she might have ignorantly made to save the woman, I am unable to state; although I strongly suspect she (the midwife) had rudely meddled with the placenta. The extensive connexion of this organ tended, no doubt, to increase the hazards which usually belong to a central position of it over the os uteri. An early and judicious delivery wonld have afforded her the best, and indeed the only, chance of being saved. The whiteness of the child's body shewed that its blood had drained away; and there is no doubt that the source from whence it escaped was the lacesated placental tissue. (Vide Lancet, loc. cit.)

CASE xvirr. June 23rd, 1847. I received a note from Mr. Dunn, requesting me to see Mrs. L., who was flooding, in consultation with him, and to bring my galvanic apparatus along with me. He stated to me that she was now in labour of her fifth child, and had previously two attacks of slight hæmorrhage, both of which had been arrested by quietude, cold applications, and an acid mixture. She was delicate leucophlegmatic woman, about 40 years of age.

When Mr. Dunn first saw her, she had felt trifling pains; and the discharge, which at first was only moderate, gradually increased. There was no obvious cause to account for either this or the two former attacks. The os uteri was thin and partially dilated. The membranes and a portion of the placenta were felt, and a little above, the head of the child presented. An abdominal bandage had been applied, and cold water and vinegar externally used. As the pains continued to come on very frequently, and were very weak, and the hæmorrhage was much greater, I was now sent for. I found this lady very feeble, evidently suffering the effects of loss of blood. Her countenance was pallid, especially the lips. The skin was pale; the pulse frequent and small; the os uteri was soft and thin, and dilated as nearly as possible to the size of a crown-piece. The pains seemed 